\title{
バイオリファイナリーの現状と展望
}

\section{Current Outlook of Biorefinery}

乾将 行・湯 川 英 明

\section{1.はじめに}

近年の石油価格の高騰や地球温暖化に対する意識の向上 が契機となり、日本国内に扔いてバイオエタノールやバイ オディーゼルが注目されている。しかし、米国では 1990 年代よりバイオエタノールを含め、バイオマスからのエネ ルギーや化学品の大規模製造を新規コンセプトの「バイオ リファイナリー」として注目し、国家戦略として技術開発 を強力に推進してきた。

こうした背景から、バイオエタノールの市場規模は予測 を上回るペースで拡大している。しかしながら、バイオ燃 料の生産急増は、原料作物や他の農産物価格の高騰、農地 拡大による森林伐採などの環境破壊を引き起こすなど、負 の側面も指摘されるようになってきた。これに対し、非可 食資源であるリグノセルロース系バイオマスからのバイオ 燃料製造は、LCA (Life Cycle Assessment)評価からも二 酸化炭素 $\left(\mathrm{CO}_{2}\right)$ 排出削減に高い効果が示されるなど、ク リーンな燃料として大きな期待を集めている。

このような状況の下、(財地球環境産業技術研究機構 (RITE)ではリグノセルロース系バイオマス、中でもリグ ニン含有量が比較的少ないソフトバイオマスからのバイオ 燃料・化学品製造技術の開発を行ってきた。本稿では、米 国におけるバイオ燃料、バイオ化学品の現状と今後の動向、 およびRITEにおける研究開発について紹介する。

\section{2. 米国におけるバイオリファイナリーの現状と今後 2.1 バイオ燃料}

米国では 1999 年の大統領令を発端にバイオマスの利用 技術開発が国家戦略の一つとして位置づけられ、エネル ギー省や農務省などの政府機関による研究支援が強化され た。2007 年の年頭教書でブッシュ前大統領は、10 年間で ガソリン使用量を $20 \%$ 削減するという意欲的な「Twenty in Ten」の目標を設定し、同年 12 月にはこれに沿ったエ

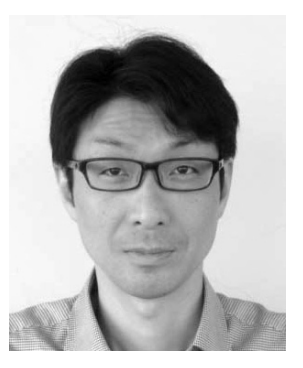

MASAYUKI INUI

(䝧地球環境産業技術研究機構 バイオ研 究グループ副主席研究員 東京工業大 学連携教授 グリーンフェノール・高 機能フェノール樹脂製造技術研究組合 技術部長 工学博士

产619-0292 京都府木津川市木津川台9-2 (䝧)地球環境産業技術研究機構(RITE) バ イオ研究グループ

Tel :0774-75-2308 Fax:0774-75-2321

E-mail : inui@rite.or.jp

〈専門〉分子生物学、代謝工学、応用微 生物学
ネルギー法案として、2022 年までに 1 億 3660 万 $\mathrm{kL}$ のエ タノールを主とするバイオ燃料の使用義務を示した Energy Independence and Security Act of 2007 (EISA 法) が発効された。このような背景の下、バイオエタノールは 生産と消費の両面から手厚い補助を受け、生産量が増加し ており、2008 年度の生産量は「EISA 2007」の 2008 年使 用義務量を超える量まで増大した。しかしながら、このよ うなバイオエタノール生産量の急増は原料作物 (コーン、 サトゥキビ)の価格急騰の要因と指摘されるなど、バイオ 燃料の負の側面も顕在化してきた。

現在、米国に押いてバイオエタノールの原料はトウモロ コシを指すが、「Twenty in Ten」計画や「EISA 法」はト ウモロコシだけを原料としたものではない。もともと農務 省は、トゥモロコシからの生産量の限界を約 2800 万 $\mathrm{kL}$ とし、それ以上の生産は、ソフトバイオマスを原料とする 計画であった。具体的には、非可食資源である農業廃棄物 (稲わら等)やエネルギー作物 (スイッチグラス等) に由来す るセルロース類を原料とするため、食料との競合を軽隇可 能としている。

\section{2 バイオ化学品}

バイオ化学品分野に打いては、当初は Du Pont のプロ パンジオール生産計画などに代表されるごとく、いわゆる “炭素数3〜6 ケの化学品製造”が主たる動きであった。 これは、既存の石油化学プロセスでは経済性を有するコス トでの製造が困難であり、バイオ技術での製造が期待され ている製品群である。

これに加えて、ごく直近、1 2 年前よりの新しい動き が、“石油化学からグリーン化学への変革”である。既存 の石油化学技術、プラントを生かし、原料をバイオマス由 来のバイオ化学品に代替するというものである。特に注目 される動きが、ポリプロピレン樹脂 $(\mathrm{PP})$ のグリーン化で

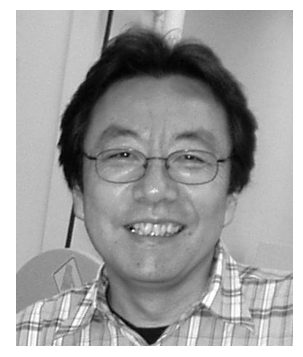

HIDEAKI YUKAWA (財地球環境産業技術研究機構 理事、バ イオ研究グループ グループリーダー 奈良先端科学技術大学院大学 連携講座 教授(客員) グリーシフェノール・高機 能フェノール樹脂製造技術研究組合 専 務理事 農学博士

務619-0292 農学博声府木津川市木津川台9-2 (財)地球環境産業技術研究機構(RITE) バ イオ研究グループ

Tel : 0774-75-2308 Fax:0774-75-2321 E-mail: mmg-lab@rite.or.jp
〈専門〉分素生物学、微生物利用学、酵 
ある。現在、自動車に使われている樹脂の 9 割が PP であ り、これのグリーン化は、 $\mathrm{CO}_{2}$ 削減効果に関して激しい競 争となっている自動車業界にとっては“垂涎の的”と言え る。

\section{3 ソフトバイオマス原料法への期待}

(1) $\mathrm{CO}_{2}$ の削減効果

米国のアカデミアで長年、論争となっていたバイオエ夕 ノールの温室効果ガス削減効果に対する LCA 評価議論に は、ほぼ結論が下されている。2004 年に国際エネルギー 機関(IEA : International Energy Agency)は、ガソリンが 排出する温室効果ガスに対しコーン原料のバイオエタノー ルでは 20〜 40\%、セルロース原料のバイオエタノールで は 70〜90\%の削減効果があるとの調査結果を発表した。 さらに、各種自動車燃料の LCA 解析評価法で最も定評の ある、米アルゴンヌ国立研究所の GREET モデルにおいて も、セルロース原料のバイオエタノールはガソリンに比ベ て温室効果ガス排出量が $25 \%$ 以下であり、他の燃料の中 で最も削減に貢献できる可能性があることを示している。

\section{（2）ソフトバイオマス原料法の経済性}

ソフトバイオマスは、商品作物に比べて気候や栽培地の 適合性に関するハードルが低く、栽培可能地域がはるかに 広い。従って、世界中で低価格なバイオ燃料の生産が可能 と期待されている。

さらに、ソフトバイオマスからのバイオ燃料生産は地政 学的なエネルギー・リスクを低減させ、貧困地域(国)の農 業振興、新規雇用の発生といったグローバルなプラスの効 果を生むことへの期待も大きい。

\section{3. ソフトバイオマス原料法の開発}

\section{1 要素技術}

ソフトバイオマスからのバイオエタノール生産は 2 つの 要素技術から構成される(図 1)。すなわち、ソフトバイオ マスからの糖類生成工程、生成糖類からエタノールへのバ イオ変換工程である。前者は使用する酵素(セルラーゼ)の コストが鍵であり、酵素メーカーによる技術改良、大規模
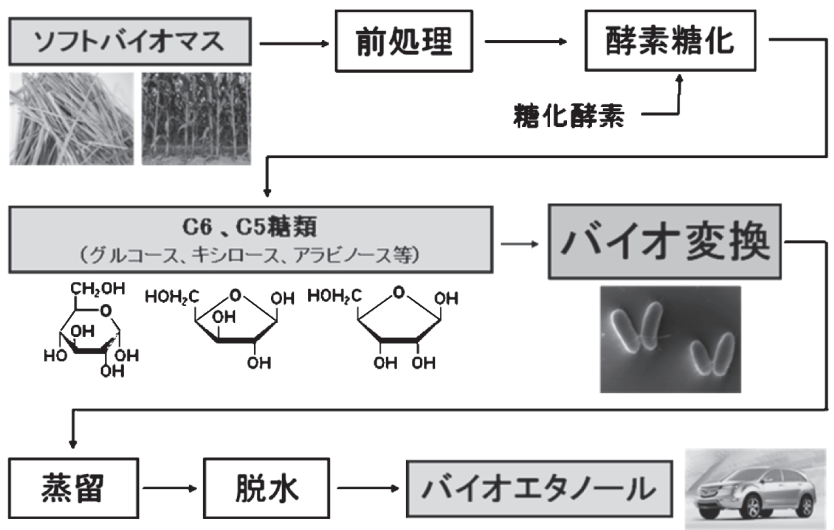

図 1 ソフトバイオマスからのエタノール生産プロセス
生産による大幅なコストダウンが見込まれている。従って、 後者のバイオ変換工程の技術確立が現在の最大の課題と考 えられている。

\section{2 バイオ変換工程に必須な技術特性}

ソフトバイオマス原料法におけるバイオ変換工程には次 の 3 つの技術特性が要求される1)。

- 高生産性

- C6、C5 糖類の同時利用

・リグノセルロース由来「発酵阻害物質」に対する耐性

デンプン系バイオマスの構成糖はグルコースなどの C6 糖類であるが、ソフトバイオマスにはキシロースやアラビ ノースなどの C5 糖類も共存する。そのため、エ夕ノール 変換工程に用いる微生物は、C6 糖類、C5 糖類を同時利用 できることが必要となる。さらに、ソフトバイオマスから の糖類生成工程では、酵素糖化を容易にするために、水熱 などによる前処理を必要とするが、バイオマスの過分解に よってフェノール類やアルデヒド類、有機酸類などが副生 成する(図 2)。これらの副生物は微生物に対して強力な生 育阻害作用を示し、「発酵阻害物質」として大きな問題と なっている。物理・化学的除去方法の開発も進められてい るが、新たな工程の追加はコスト高になるため、発酵阻害 物質に影響を受けない開発技術が求められている。

従来の酒やワインの発酵生産に用いられてきた酵母など の微生物は、デンプン系バイオマス原料法には利用できる が、ソフトバイオマス原料法に利用するには上述の技術特 性をクリアすることが課題となっている。

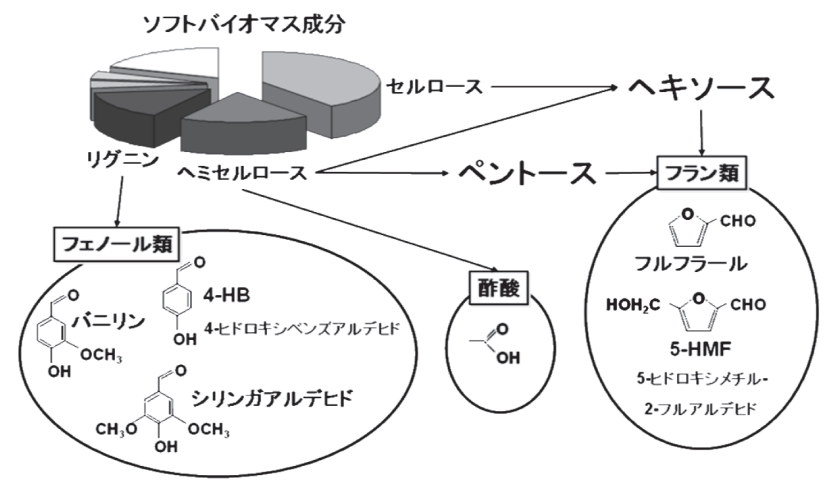

図 2 主な発酵阻害物質

E. Palmqvist, B. Hahn-Hägerdal Bioresource Technology 74 (2000) 25-33、より改変

\section{RITE における技術開発}

我々はこれまでに、工業的に多用され優秀な物質生産能 を所持するコリネ型細菌を用いた、新規コンセプトに基づ く高生産性バイオプロセス「RITEバイオプロセス」の基 盤技術を確立している ${ }^{2-5)}$ 。この技術をソフトバイオマス からのバイオエタノール生産プロセスの開発に応用し、世 界に先駆けて前記の技術特性の確立の目処を得た。以下に その特徴について紹介する。 


\section{1 高生産性 RITE バイオプロセス}

RITE バイオプロセスの高効率の鍵は、眓 3 に示すよう に微生物細胞の分裂増殖を人為的に停止した状態で化合物 を製造させることにある。このプロセスでは、遺伝子レべ ルで機能改善した微生物細胞 (RITE 菌; Corynebacterium glutamicum R) を大量に培養し、反応槽に高密度に充填す る。そして細胞の分裂増殖を停止させた状態で高速度の反 応を行う。これにより微生物細胞をあたかも化学プロセス における触媒のように利用でき、通常の化学プロセスと同 等以上の生産性 (space time yield; STY、単位反応容積の 時間あたりの生産量)が実現される ${ }^{2-5)}$ 。この技術を応用し たバイオエタノール生産に関しても従来の発酵プロセスと 比較して格段に高い生産性を実現した6)。

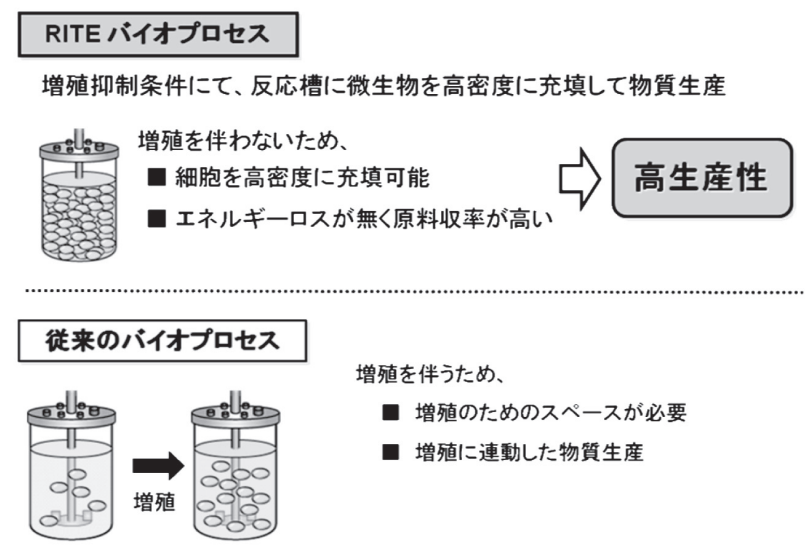

図 3 RITE バイオプロセスと従来法との比較

\section{2 高生産性「エタノール RITE 菌」の創製}

RITE では近年急速に進歩したシステムバイオロジーに 基づいて微生物細胞を開発するための基盤技術として、C. glutamicum R の全ゲノム配列の解読を終了し ${ }^{5)}$ 、遺伝子レ ベルでの革新的改良法を確立している ${ }^{78)}$ 。この技術を応用 して、コリネ型細菌にエタノール高生産性能力を付与した 「エタノール RITE 菌」の構築に成功した6)。

\section{$4.3 \mathrm{C} 6$ 糖類、C5 糖類の同時利用}

RITE 菌には、ソフトバイオマスに含まれる C5 糖類利 用のために、キシロースおよびアラビノース利用に関与す る他微生物由来遺伝子を導入している-13)。さらに、RITE 菌を用いた RITEバイオプロセスにおいては、C6 糖類お よびC5 糖類の完全同時利用を確認しており、効率的な原 料利用が可能となっている。

\section{4 発酵阻害物質に対する高度耐性}

RITE バイオプロセスにおいては、フェノール類やアル デヒド類、有機酸類などの発酵阻害物質によるエタノール 生産性の低下がないことを認めている ${ }^{14)}$ 。発酵阻害物質の 作用機構は增殖阻害であるが、本プロセスにおいて微生物 細胞は非増殖状態にあることから、エタノール生産に関与 する代謝には影響を与えないことを明らかにした。

\section{5 工業化に向けた取り組み}

上述のように、RITE ではソフトバイオマス原料法にお ける技術要素確立の目処を得たことから、早期工業化を目 指し、2006 年 9 月に(株)本田技術研究所との共同研究開発 を表明した。2007 年 4 月より、(株本田技術研究所の研究 センター内において、工業化基礎検討を進めており、これ までに工業化基礎データの取得を完了した。現在、工業生 産へ向けて FS(Feasibility Study)を開始している。

\section{5. おわりに}

ソフトバイオマスからのバイオエタノール製造法に関し ては基礎研究段階を既に過ぎ、工業化の検討段階となって いる。一方、基礎研究レベルにおいては、ソフトバイオマ ス原料からのバイオブタノール生産が注目されている。ブ タノールはディーゼルエンジンの燃料である軽油への混合 が可能なバイオ燃料であり、地球環境と経済性で大きな問 題を抱えている既存の植物油由来のバイオディーゼル燃料 に代替できることから実用化への期待は大きい。

2009 年 1 月に就任したオバマ大統領はエネルギー新政 策「New Energy for America」を発表し、今後 10 年間で 1500 億ドル (約 13 兆 5000 億円) を再生可能エネルギーな どの事業に注ぎ、 500 万人の雇用を創出する目標を示した。 さらに、自然エネルギーを導入割合で 2025 年までに $25 \%$ 、 温室効果ガスを 2050 年までに 1990 年度比で $80 \%$ 削減す る長期目標も掲げている。こういった地球温暖化対策に関 する動きは、今後も世界レベルで拡大し続けると予想され る。我々 RITEもこのような動きの一端を担うべく、バイ オエネルギーの革新的製法確立に向けて引き続き全力で研 究に取り組んでいきたい。

\section{引用文献}

1) Dien, B. S., Cotta, M. A., and Jeffries, T. W. (2003) Appl Microbiol Biotechnol 63, 258-266

2) Inui, M., Murakami, S., Okino, S., Kawaguchi, H., Vertès, A. A., and Yukawa, H. (2004) J Mol Microbiol Biotechnol 7, 182-196

3) Inui, M., Suda, M., Okino, S., Nonaka, H., Puskas, L. G., Vertès, A. A., and Yukawa, H. (2007) Microbiology 153, 2491-2504

4) Okino, S., Inui, M., and Yukawa, H. (2005) Appl Microbiol Biotechnol 68, 475-480

5) Yukawa, H., Omumasaba, C. A., Nonaka, H., Kós, P., Okai, N., Suzuki, N., Suda, M., Tsuge, Y., Watanabe, J., Ikeda, Y., Vertès, A. A., and Inui, M. (2007) Microbiology 153, 1042-1058

6) Inui, M., Kawaguchi, H., Murakami, S., Vertès, A. A., and Yukawa, H. (2004) J Mol Microbiol Biotechnol 8, 243-254 
7) Suzuki, N., Okayama, S., Nonaka, H., Tsuge, Y., Inui, M., and Yukawa, H. (2005) Appl Environ Microbiol 71, 3369-3372

8) Vertès, A. A., Inui, M., and Yukawa, H. (2005) Appl Environ Microbiol 71, 7633-7642

9) Kawaguchi, H., Sasaki, M., Vertès, A. A., Inui, M., and Yukawa, H. (2008) Appl Microbiol Biotechnol 77, 10531062

10) Kawaguchi, H., Sasaki, M., Vertès, A. A., Inui, M., and Yukawa, H. (2009) Appl Environ Microbiol 75, 34193429
11) Kawaguchi, H., Vertès, A. A., Okino, S., Inui, M., and Yukawa, H. (2006) Appl Environ Microbiol 72, 34183428

12) Sasaki, M., Jojima, T., Inui, M., and Yukawa, H. (2008) Appl Microbiol Biotechnol 81, 691-699

13) Sasaki, M., Jojima, T., Kawaguchi, H., Inui, M., and Yukawa, H. (2009) Appl Microbiol Biotechnol 85, 105115

14) Sakai, S., Tsuchida, Y., Nakamoto, H., Okino, S., Ichihashi, O., Kawaguchi, H., Watanabe, T., Inui, M., and Yukawa, H. (2007) Appl Environ Microbiol 73, 2349-2353 